\title{
Micro, Small and Medium Enterprises in West Bengal-An Inter-District Analysis
}

\author{
Krishna Sen ${ }^{1}$, Seikh Salim ${ }^{2}$ \\ ${ }^{1}$ Research Scholar, Dept. of Economics, University of Burdwan, West Bengal, India
}

\author{
${ }^{2}$ Associate Professor\& In-charge (Evening Shift), Burdwan Raj College, University of Burdwan, West Bengal, India
}

\begin{abstract}
Present study deals with the importance of the Micro, Small and Medium Enterprises (MSMEs) in West Bengal. MSMEs plays an important role in Indian economy due to its greater resource, capacity for employment generation, technological innovation, raising exports and developing entrepreneurial skills. In West Bengal, there is high regional disparity in the growth of MSME sector.Realizing the importance of this sector, Government of West Bengal along with Government of India introduces certain schemes to develop district wise industries. However,still now there are some problems associated with MSMEs, like lack of capital sufficiency, lack of entree to global market, high cost of credit, problems of stuffing, planning and product display, inadequate infrastructure facilities etc. To eradicate these fundamental problems, the policy makers and the entrepreneurs must work together and can provide us well developed economy.
\end{abstract}

Keywords: Micro and Small Scale Enterprises, Employment generation, Regional disparity, Sickness.

\section{Introduction}

Micro, Small and Medium Enterprises (MSMEs) across the world, including India, are the vehicles for faster, sustainable and overall inclusive economical growth. In India, the MSME sector is a founding pillar of its socio-economic fabric. With more than 44.7 million enterprises, this sector generates more than 101 million jobs; second largest sector afteragriculture.Italso contributes $40 \%$ of total industrial manufacturing and $43 \%$ of Indiaes total exports. There are over 8,000 products ranging from traditional to high-tech items, which are being manufactured by the MSME sector in addition to provide wide range of services. In modern era, with the development of Indian economy and rapid expansion of trade, this sector has emerged as anenthusiastic and dynamic segment in the process of industrialization which is considered not only as a key factor to lift up the per capita income but also a vital mechanism for a larger transformation of Indian economy.

Table 1: Limit for Investment in Plant \& Machinery and Equipment

\begin{tabular}{|c|c|c|}
\hline $\begin{array}{c}\text { Enterprises } \\
\text { (Type) }\end{array}$ & $\begin{array}{c}\text { Investment in Plant \& } \\
\text { Machinery(Manufacturing) }\end{array}$ & $\begin{array}{c}\text { Investmentin } \\
\text { Equipment(Service) }\end{array}$ \\
\hline Micro & Up to Rs. 25 lakh & Up to Rs. 10 lakh \\
\hline Small & $\begin{array}{c}\text { Above Rs. 25 lakh up to Rs. } \\
5 \text { crore }\end{array}$ & $\begin{array}{c}\text { Above Rs. 10 lakh } \\
\text { up to Rs. 2 crore }\end{array}$ \\
\hline Medium & $\begin{array}{c}\text { Above Rs.5 crore up to Rs. } \\
10 \text { crore }\end{array}$ & $\begin{array}{c}\text { Above Rs. } 2 \text { crore } \\
\text { up to Rs. } 5 \text { crore }\end{array}$ \\
\hline
\end{tabular}

(As per Micro, Small and Medium Enterprises Development Act, 2006)

„Micro ${ }^{\text {, , }, S m a l l}{ }^{\text {ee }}$ and „Medium enterprises have been widely defined in the Micro, Small and Medium Enterprises Development (MSMED) Act, 2006. The Act provides the first-ever legal framework for recognition of the concept of "enterprise". Under this Act, enterprises have been categorized broadly into those engaged in manufacturing and those providing/rendering services. Both the categories have been further classified into micro, small and medium enterprises based on their investment in plant and machinery (for manufacturing enterprises) or in equipment (in case of enterprises providing or rendering services) as shown in table 1 .

According to $4^{\text {th }}$ Census of MSMEs.West Bengaloccupies $6^{\text {th }}$ positionin India in terms of numbers of small scale enterprises (after Uttarpradesh, Andhrapradesh, Maharastra, TamilNadu and Madhyapradesh). In terms of employment generation in thissector, West Bengal ranks $2^{\text {nd }}$ after U.P. Nearly 25.22 lakh people are employed in West Bengal in small scale industry.In West Bengal, the MSMEs account for nearly $90 \%$ of the industrial units and more han $50 \%$ of industrial production. The export from this sector is about $40 \%$ of the total export from the state. The state is considered as one of the most anticipated industrial location for setting industries in the country. The state has been consistently pursuing progressive outlook to meet the changing needs of the state economy and industry. Furthermore, West Bengal is also considered as one of the countries industrialists ${ }^{\text {ee }}$ state comprising large public sector industrial undertakings, large privately owned industries like steel, leather, textiles etc.

Government of West Bengal states its mission to create additional employment for about 10 million people in next 10 years in the state in the MSME sector and its vision is to create a sustainable eco-system to maximize the utilization of resources and widen the area of operation. The micro and small enterprises play a very vital role in the initiatives for socio-economic development of people in the state. Directorate of MSME under the Department of Micro, Small \& Medium Enterprise and Textiles (MSME\&T), Government of West Bengal is the nodal agency for the growth and promotion of this sector. In the current year (2014-15), 7647 MSME units have already been registered in EM-II with an investment of Rs. 848.01 crore by providing employment to 86986 persons (Economic Review 2014-15). In the previous year (2013-14), 11,380 enterprises filed EM-II after commencement of production which 
provided 1,02,802 employment with Rs. 869.83 crore investments.

The present study investigates the district wise contribution of MSMEs in West Bengal. Distribution of Micro and Small Scale Enterprises(MSSEs) among 19 districts of the state has significant variations. Burdwan, Howrah, Hoogly, South 24 Parganas, Kolkata, Nadia, DakshinDinajpur and Jalpaiguri are key districts accounting for large portion of state enterprises. While Purulia, Bankura, Uttar and Dakshin Dinajpur, PaschimMidnaporeare treated as backward districtswith sloppy industrial growth, not remarkable progress in the secondary and tertiary sectors.

\section{Review of Literature}

For the purpose of the research work, different books, journals, research papers and articles were consulted.Mukherjee. R. (1999) pointed out that in Indian perspective the growth in number of units and employment has not been uniform. In his study, West Bengal was selected for study and growth rates were calculated by districts for unit and employment separately during 1971 to 1997.There exist a considerable difference in the rates across districts and the year to year growth rates do not fluctuate much overtime for any one district.Ganguly.S. (2013) also showed the importance of MSMEs in West Bengal.The MSMEs (basically micro and small enterprises) in West Bengal face very tough situation due to utmost competition in national and international level from large industries due to lack of infrastructure, lower volume of capital, lack of product standardization, lack of access to modern technology etc. Another important problem of MSMEs in West Bengal is the number of unregistered MSMEs is much higher than the registered units.Lahiri. R. (2014) analysed the ground reality of MSMEs at Howrah district in West Bengal. He tried to find out the scenario of institutional credit support by the banks and rank the major problems faced by the MSMEs. He explored that the most vital problems of MSMEs at Howrah are poor banking support, obsolete technology, competition, labor problems, infrastructural deficiency, etc.Sathish. A. (2014) showed the trend of MSME in terms of number of unit, employment and investment in Goa from 2007-08 to 2013-14. He also briefly discussed the issues related to closure of units.Rangacharya. K. (2014) attempted to analyses the growth trends of SMEs in Karnataka after enactment of MSMED Act 2006, and discussed the investment, employment, production and export performance of the SMEs in Karnataka state.

\section{Objectives of the study}

Present study was undertaken with the following objectives:

- To study the performance of MSME in terms of number of units, employment and investment in West Bengal.

- To analyze the regional disparity through district wise performance of MSME in West Bengal.

- Find key challenges faced by MSMEs in West Bengal.

\section{Research Methodology}

\subsection{Period of the Study}

For the purpose of this study, the period after the introduction of MSME Act 2006 is consideredi.e. the required data is collected from the period 2006-07 to 201314 (Eight Years).

\subsection{Sources of Data}

Secondary data were collected from different sources like Final Report of $4^{\text {th }}$ All India Census of MSMEs, published annual report of MSMEs, Economic Review of West Bengal, Annual Report of SIDBI, Report of Department of MSME\&T, journals, magazines, internet database, research papers, related books and thesis etc.

\subsection{Analytical Tools}

For the purpose of this study, simple bar diagramis used to show and represent data to make the better understanding of available data.

\section{Growth of MSSE/MSME Units, Employment and Investment in West Bengal}

West Bengal occupies a place of pride in the industrial map of India which is attributable to its micro, small, medium industrial sector. West Bengal has the tradition in deploying the available resources to develop the industrial base. The Govt. of West Bengal is taking major initiatives to develop MSME sector with topmost priority for industrialization in the state. West Bengal, with its broad customer base, rich mineral resources and large talent pool, could emerge as one of the leading states to drive the next phase of industrialization in the country. Of the important mineral resources, the state have huge deposit of coal and iron ore. The state is also being strategically positioned for bilateral trade with Bangladesh, Nepal, Bhutan, Myanmar and ready access to South East Asian countries, over and above the domestic market. Table 2represents yearwise registered Micro, Small and Medium Enterprises, Employment and Investment of West Bengal.

Table 2: Year wise trend of registered enterprises, employment and investment in West Bengal

\begin{tabular}{|c|c|c|c|c|c|}
\hline Year & Micro & Small & Medium & Employment & Invest.(Cr) \\
\hline $2006-07$ & 41420 & 1758 & 81 & $3,65,228$ & 338054 \\
\hline $2007-08$ & 16510 & 1108 & 0 & $1,83,242$ & 135946 \\
\hline $2008-09$ & 12470 & 945 & 13 & $1,37,150$ & 126410 \\
\hline $2009-10$ & 10934 & 734 & 17 & $1,31,669$ & 89965 \\
\hline $2010-11$ & 9504 & 595 & 10 & $1,21,944$ & 77788 \\
\hline $2011-12$ & 12736 & 723 & 11 & $1,20,446$ & 125548.3 \\
\hline $2012-13$ & 9728 & 602 & 12 & N.A & N.A \\
\hline $2013-14$ & 10651 & 729 & 0 & $1,02,802$ & 869.83 \\
\hline
\end{tabular}

Source:Directorateof Micro, Small \& Medium Enterprise and Textiles (MSME\&T), Government of West Bengal. Entrepreneur Memorandum Part-II 2007-08 to 2013-14, 
Ministry Of Micro, Small \& Medium Enterprises.N.A: Not Available.

Above data portray that in past eight years, more of Micro enterprise has gone for filling EM-II compare to small and medium enterprises.The employment and investment also deteriorate during the study period. Due to lack of administrative demand or introduction of the Micro, Small and Medium Enterprises Development Act, in October, 2006, the registration system has been abolished therefore most of the entrepreneurs do not come forward for filing EM Part-II Registration. As a result the statistical data of such unregistered units are not available from the Department and we get mismatch figures of provisional \& perpetual units. According to the $4^{\text {th }}$ census of MSME,the ratio of registered and unregistered units in West Bengal is 1:48.

\section{Role of District Industries Centre (DIC) in West Bengal}

The 'District Industries Centre' (DICs) programme was started by the central government in 1978 with the objective of providing a focal point for promoting small, tiny, cottage and village industries in a particular area and to make available all necessary services and facilities at one place.

The Head Quarters of the Directorate of Micro,Small \& Medium Enterprises is located at Kolkata. There are 22 District Industries Centres and Sub-DICs. In each District Industries Centre, there are groups of Managers in the rank of Asst. Director and also a number of Industrial Development officers to assist the General Manager who is the organizational Head of the District.

The main objective of the Directorate is to facilitate growth and promote MSE, Cottage, Handicrafts, Coir \& Lac Sector and to impart training to new and old entrepreneur. The motto of the team of the Directorate either at the Head Quarter, or in the District / Block level is to identify and train prospective entrepreneur and to extend infrastructure support to the entrepreneur of the State.

The Directorate of Micro,Small \& Medium Enterprises tries to develop the enterprises by harnessing the existing resources and new fast growing infrastructure facilities in the state. EDP(Entrepreneur Development Program) training programmes are in vogue for existing and new prospective entrepreneurs for development of their managerial as well as technical skill. Awareness/ motivational programmes are convened in the polytechnics and engineering colleges to overcome the shyness in entrepreneurship due to the job seeking attitude of educated youths.Various activities \& schemes implemented are :

1) National Manufacturing Competitiveness Programme.

i. Support for Entrepreneurial and Managerial Development of SMEs through Incubators.

ii. Enabling Manufacturing Sector to be competitive through Quality Management Standard \& Quality Tech. Tools (QMS/QTT).

iii. Building awareness on Intellectual Property Rights (IPR) for MSME.

iv. Lean Manufacturing Competitiveness Scheme for MSMEs.

v. Mini Tool Rooms proposed to be set up by Ministry of MSME.

vi. Design Clinic Scheme for design expertise to MSMEs manufacturing sector.

vii. Marketing assistance \& technology upgradation scheme in MSMEs.

viii. Technology and quality upgradation support to MSMEs.

ix. Promotion of Indian Manufacturing Sector.

2) Micro \& Small Enterprises Cluster Development Programme.

3) Credit Guarantee Fund Scheme for micro \& small enterprises.

4) Market Development Assistance Scheme.

5) Credit Linked Capital Subsidy Scheme.

6) Incentive for ISO-9001/14001 Certification.

7) Incentive for Bar Code Registration \& Annual Renewal.

8) Scheme for Capacity Building Strengthening of Data base, etc.

9) National Awards for small scale sector.

\section{District-wisedistribution of industries}

West Bengal has industries like Tea,Petroleum and Petrochemicals, Leather,Iron and Steel, IT, Mineral resources, Automobile and auto components, Biotechnology, Fisheries, Agriculture and Horticulture, Livestock and Dairy products, Chemicals, Textiles, Jute products, Vegetable oils, Electronics, Engineering goods etc (Table 3).

\begin{tabular}{|c|c|c|}
\hline S.No. & District & Key Industries \\
\hline 1 & Bankura & $\begin{array}{c}\text { Food and Food-Processing Industries,Chip Stone, Textile Product, Ply-Wood Industry and Veneer Mills, } \\
\text { Paper Industry, Particle Board etc. }\end{array}$ \\
\hline 2 & Birbhum & Woolen, silk \& artificial Thread based clothes, Paper \& Paper products, Leather based \\
\hline 3 & Burdwan & $\begin{array}{l}\text { Iron \& steel industries, Fertilizers Industries, Mining Industries, Equipment Manufacturing, Electrical } \\
\text { machinery and transport Equipment, Cement Industry, Rice and Oil seed Mills, cutlery etc }\end{array}$ \\
\hline 4 & Coochbihar & $\begin{array}{c}\text { Fertilizer Industries, Jute Twine and Weaving Industry, Electrical Casing Industry, Mustard Oil Mill and Fruit } \\
\text { processing etc. }\end{array}$ \\
\hline 5 & D. Dinajpur & $\begin{array}{c}\text { Agro Food-Based Industry, Mineral and Forest-Based Industry, Chemical Based Industry, Handicrafts, } \\
\text { Engineering, Automobiles Servicing etc. }\end{array}$ \\
\hline 6 & Darjeeling & Tea industries and Tourism Industry \\
\hline 7 & Hooghly & Rice Mills, Rubber Factories, Chemical Factories etc. \\
\hline
\end{tabular}




\section{International Journal of Science and Research (IJSR) \\ ISSN (Online): 2319-7064 \\ Index Copernicus Value (2013): 6.14 | Impact Factor (2014): 5.611}

\begin{tabular}{|c|c|c|}
\hline 8 & Howrah & $\begin{array}{c}\text { Foundry, Re-Rolling Mills, Basic Metal \& Metal Products, Electrical \& Electronic, Transport Equipment\& } \\
\text { Spares,and RubberMoulded Goods, Manufacturing Industry and Jute \& jute based etc. }\end{array}$ \\
\hline 9 & Jalpaiguri & $\begin{array}{r}\text { Leather based, Chemical/Chemical based,Mineral based,Electrical machinery and transport Equipment and } \\
\text { Woolen, silk \& artificial Thread based clothes. }\end{array}$ \\
\hline 10 & Kolkata & $\begin{array}{r}\text { Paper \& Paper products, Leather based, Ready-made garments \& } \\
\text { Embroidery, Metal based (Steel Fab.), Woolen, silk \& artificial Thread based clothes, Jute \& jute based. }\end{array}$ \\
\hline 11 & Malda & Agro based, Cotton textile, Woolen, silk \& artificial Thread based clothes, Wood/wooden based furniture. \\
\hline 12 & Murshidabad & Paper \& Paper products, Leather based, Chemical/Chemical based and Mineral based. \\
\hline 13 & N.24 Pargana & Printing, Book Binding, Cement Manufacturing, Oil Seed Milling, General Electrical Works etc. \\
\hline 14 & Nadia & Food and Fruit Processing, Jute Diversified, Pipes \& Tubes, Electronic and computer peripherals etc. \\
\hline 15 & Paschim & Leather based, Rubber, Plastic \& petro based, Chemical/Chemical based \\
\hline 16 & PurbaMidnapur & $\begin{array}{r}\text { Fruits \& Vegetable processing, Cashew nut Processing, Horn Products, Embroidery Garments manufacturing, } \\
\text { Plastic moulded products, Engineering based units etc. }\end{array}$ \\
\hline 17 & Purulia & Spong Iron Industry and Non-Metallic Mineral Product Industry etc \\
\hline 18 & S. 24 Pargana & Cement Industry, Agro-Industry, Chemical Industry, Equipment Manufacturing Industry, FMCG Industry etc. \\
\hline 19 & U. Dinajpur & Agriculture and Allied Industries, Food Products, Hosiery and Garments, Chemical Industry, Engineering and \\
& & Fabrication etc \\
\hline
\end{tabular}

Source: District Website

West Bengal is one of the leading foreign exchange earning State from exports of items like tea, rice, floriculture products, processed foods, jute products, silk yarn and fabrics, readymade garments, carpet, leather and leather products, rubber manufactured products, paints, varnishes and enamels, drugs and pharmaceuticals, agro-chemicals, gems and Jewellery, iron and steel, machinery, transport equipment, computer software and sports goods.

\section{District-wise registered MSSE/MSME units in West Bengal}

District wise distribution of registered MSSE/MSME units during 2006-07 to 2013-14 is presented in the chart 1.

Chart 1: Cumulative number of total registered units from 2006-07 to 2013-14

\begin{tabular}{|r|r|}
\hline Kolkata & 15530 \\
N.24 Pargana & 12616 \\
Howrah & 7150 \\
S.24 Pargana & 7403 \\
Burdwan & 6026 \\
Jahaiguri & 5863 \\
Paschim Midnapur & 4567 \\
Hooghly & 4408 \\
Purba Midnapur & 4259 \\
Nadia & 4071 \\
Murshidabad & 3752 \\
Malda & 2892 \\
Birbhum & 2749 \\
Bankura & 2640 \\
Coochbihar & 2142 \\
Purulia & 1964 \\
U. Dinajpur & 1412 \\
D. Dinajpur & 956 \\
Darjeeling & 792 \\
\hline
\end{tabular}

Source: Directorate of Cottage and Small Scale Industries; Directorate of Micro and Small Scale Enterprises, Govt. of West Bengal.
From the above bar chart it is clear that, Kolkata is in $1^{\text {st }}$ position of new registered MSME unitsfrom 2006-07 to 2013-14 in West Bengal and after that North 24 Parganas is in $2^{\text {nd }}$ position and Howrah is in $3^{\text {rd }}$ position. Besides,Bankura, Coochbihar, Purulia, Uttar Dinajpur, DakshinDinajpur and Darjeelingse contribution is very insignificant and regional disparity is seen prominently among districts.

\section{District-wise distribution of employment generation through MSSE/MSME units in West Bengal}

District wise distribution of employment generated through MSSE/MSME units during 2006-07 to 2011-12 is presented in the chart 2.Regional deviations in employment generation are noticeable from the chart.

Chart 2: Cumulative number of registered employment generation from 2006-07 to 2011-12

\begin{tabular}{|r|r|}
\hline Howrah & 103728 \\
Kolkata & 95870 \\
N.24 Pargana & 90528 \\
S.24 Pargana & 69268 \\
Murshidabad & 48628 \\
Hooghly & 41793 \\
Birbhum & 41463 \\
Burdwan & 34452 \\
Purba.. & 25873 \\
Jatpaiguri & 23278 \\
Nadia & 22067 \\
Paschim.. & 21740 \\
Malda & 15007 \\
Bankura & 14304 \\
Purulia & 11790 \\
Coochbihar & 9958 \\
U. Dinajpur & 7469 \\
D. Dinajpur & 5527 \\
Darjeeling & 3216 \\
\hline
\end{tabular}




\section{International Journal of Science and Research (IJSR) \\ ISSN (Online): 2319-7064 \\ Index Copernicus Value (2013): 6.14 | Impact Factor (2014): 5.611}

Source: Directorate of Cottage and Small Scale Industries; Directorate of Micro and Small Scale Enterprises, Govt. of West Bengal.

Kolkata, Howrah, North \& South 24 Parganas, Burdwan and Murshidabad are accounting for nearly two thirds of the total employment generation from this category during 2006-07 to 2011-12. On the other hand, Bankura, Purulia, Malda, Cooch Behar,Uttar and DakshinDinajpur, Darjeeling were unsuccessful to generate new work opportunities much through MSMEs.

The above bar chart also depicted that, Howrah is in $1^{\text {st }}$ position of generating new employment opportunities from 2006-07 to 2011-12 in West Bengal and after that Kolkata is in $2^{\text {nd }}$ position and North 24 Parganas is in $3^{\text {rd }}$ position.

\section{District-wise distribution of investment through MSSE/MSME units in West Bengal:}

District wise distribution of investment in registered MSSE/MSME during 2006 to 2011 is presented in chart 3.

As per data received from the Directorate of MSMEs, Govt. of West Bengal, Howrah is in $1^{\text {st }}$ position of increase in investment from 2006-07 to 2011-12 in West Bengal and after that Kolkata is in $2^{\text {nd }}$ position and North 24 Parganas is in $3^{\text {rd }}$ position.

Chart 3: Cumulative number of registered investment from 2006-07 to 2011-12

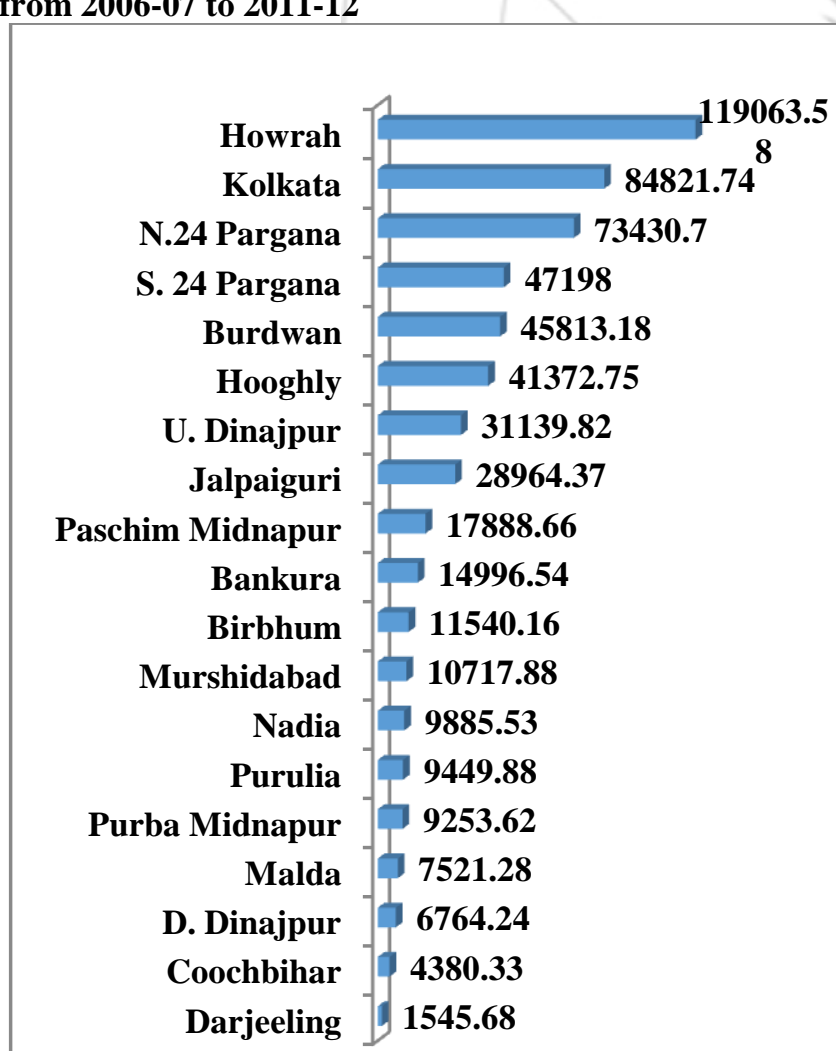

Source: Directorate of Cottage and Small Scale Industries; Directorate of Micro and Small Scale Enterprises, Govt. of West Bengal.
WBFC is a state levelappex institution of MSME sector and West Bengal Government control more than 90\% share of the corporation. Year after year their assistance are more or less in increasing trend. But their assistance is mostly around developed districts like Kolkata, Howrah, Burdwan and at the same time few districts like West Dinajpur, Coach behar, PaschimMedinpur, Uttar Dinajpur are totally neglected to get assistance. So this may leads a regional imbalance in the growth of MSME sector.

\section{Sickness of MSEs in West Bengal}

MSEs in West Bengal need support not just at the start-up stage but also for dealing with intractable issues like bankruptcy. There is a need for an Expert Advisory Group that can lay down requisite procedures and push for amendments to the existing laws to facilitate restructuring or closure of distressed MSE units.

During the past few years, sickness in industries has become a very thought provoking and obvious offshoot of the modern jet age industrial society.In overall India, there are sick MSME up to March 2013 was 2, 48,890 which was increased from 88,635 in March 2012 on account of revision of definition of sickness made by RBI in Nov, 2012.From chart 4, it is clearly depicted that from 2010-11 to 2013-14, the number of sick units in West Bengal has increased from 8,363 to 23,170 that is increasing in trend.

Chart 4: Number of Sick Enterprises in West Bengal and India

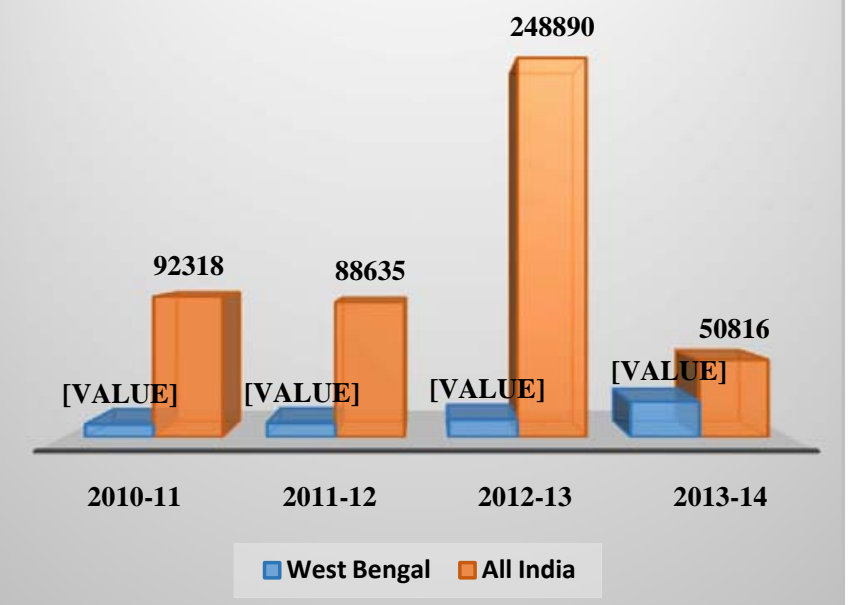

Source: Provisional data compiled by RBI 2013-14.

Some of the reasons for closures figured out during the study period could be summed up as follows:

1. Faulty project selection

2. Shortage of working capital.

3. Delay in disbursement of loans

4. Lack of demand.

5. Insufficient supply of raw materials.

6. Lack of modern technology.

7. Marketing problems.

8. Lack of trained, technical skilled workers. 


\section{International Journal of Science and Research (IJSR) \\ ISSN (Online): 2319-7064 \\ Index Copernicus Value (2013): 6.14 | Impact Factor (2014): 5.611}

9. Lack of modernization.

10. Lack of sufficient infrastructural facilities, such as, poor condition of roads, high rate of tariff on some raw materials, increased competition from multinationalcompanies.

11. Delay in detection of early symptoms of sickness.

12. Social problems like strikes, bandhs, insurgents, extortions.

13. Delay in decision and action to rehabilitate the unit etc.

\section{Conclusion}

The Micro, Small and Medium Enterprises (MSMEs) have been accepted as the engine of economic growth and play an important role in the equitable economic development of country. The major advantage of the sector is its employment potential at low capital cost.The major finding of this paper is that there exist regional variations among districts in West Bengal in case of MSME units, employment and investment.The particular complications face by the state is that lack of entree to global market, high cost of credit, problems of stuffing, planning and product display, inadequate infrastructure facilities etc. However facilitation from the government is required to minimize transaction cost of technology upgradation, market penetration, mordernisation of infrastructure etc. Considering the increasing insurgency problems in the state, outside entrepreneurs are hesitant to come to the insurgency stricken state for establishing their industrial units.Problems in land acquisition are yet another reason behind the failure of the industrial policy. However, as the majority of land in West Bengal is agricultural, its acquisition is an issue. The challenge for the government is to address the issue from a holistic perspective, striking a balance between agriculture and industry.To facilitate growth in the micro, small and medium enterprises (MSMEs) sector, industrial clusters need to be created to ensure common facilities, thereby reducing operating costs, increasing competitiveness and developing skills for the sector.If governments financial assistance is not properly reached to every corner of the state it may have strong negative impact on the development of state industry. Therefore, it is suggested to state government to open special branches in backward districts for MSME sector to ensure increased flow of credit.

\section{References}

[1] Annual Report (2013-14). MSME-Development Institute of Kolkata. www.msmedikolkata.gov.in

[2] Bhat, F. A. (2012). Economics of Small Scale Industrial Sector in J\& K.....A Case Study of District Budgam. P.G. Department of Economics, University of Kashmir, Srinagar 190006, J \& K.

[3] Dagadu, G. M. (2013). Sickness in Small Scale Industries: Causes and Remedies:A Case Study of Aurangabad. Excel Journal of Engineering Technology and Management Science. Vol. I, No. 3.

[4] Economic Review of West Bengal 2014-15.

[5] Entrepreneurs Memorandum Part-II (2007-08 to 201314). Ministry of Micro, Small \& Medium Enterprises.

[6] Ganguly, S. (2013). Micro, Small and Medium Enterprises in West Bengal: An Evaluation. International Journal of Research in Commerce and
Management. Volume No. 4, Issue No. 10 http://ijrcm.org.in/

[7] Gupta, S. (2009). Future Prospects of Small Scale Industrial Sector of Punjab: an Empirical Assessment. IBIMA, Volume 7, ISSN: 143-7765.

[8] Kanrar, S. (2013). Disparity in Institutional Financing in the Development of MSME in West Bengal: A Case Study on West Bengal Financial Corporation. The Management Accountant. Vol. 48, No. 5. www.icmai.in

[9] Lahiri, R. (2014). A Case Study on the Opportunities and Challenges of Micro, Small and Medium Enterprises (MSMEs) at Howrah District in West Bengal. International Journal of Management Research and Business Strategy. Vol. 3, No. 4. www.ijmrbs.com.

[10] Mukherjee, N. (1997). Small Scale Industries- Problems and Prospects in West Bengal with Special Reference to Darjeeling District (1951- '85). Kolkata: Progressive Publishers. www.globalbizresearch.org

[11] Mukherjee, R., Das, P.K., Batyacharya, U. (1999). Small Scale Industries in West Bengal 1971-97. EPW. Vol.XXXIV, No. 48.p.M157-162.

[12] Rangacharya, K. (2014). Role of SMEs in Development of Karnataka Economy. Indian Streams Research Journal. V olume-3, Issue-12. www.isrj.net.

[13] Ray, S. (2014). An Analysis ofPerformance, Growth and Prospects of Micro, Small and Medium Enterprises in India. United States of America Research Journal. Vol. 2, No. 2. www.usarj.org

[14] Sathish, A. (2014). Issues and Problems in the Growth of Micro, Small and Medium Enterprises in Goa: An Empirical Study. International Journal of Science and Research. Volume 3, Issue 7, www.ijsr.net. 